Prepared for the U.S. Department of Energy

under Contract DE-AC05-76RL01830

\title{
Summary of the Undergraduate Mentoring Assistance Program for PNNL
}

PNNL.12.007

(June 2012 - September 2012)

JM Schwantes

March 31, 2013

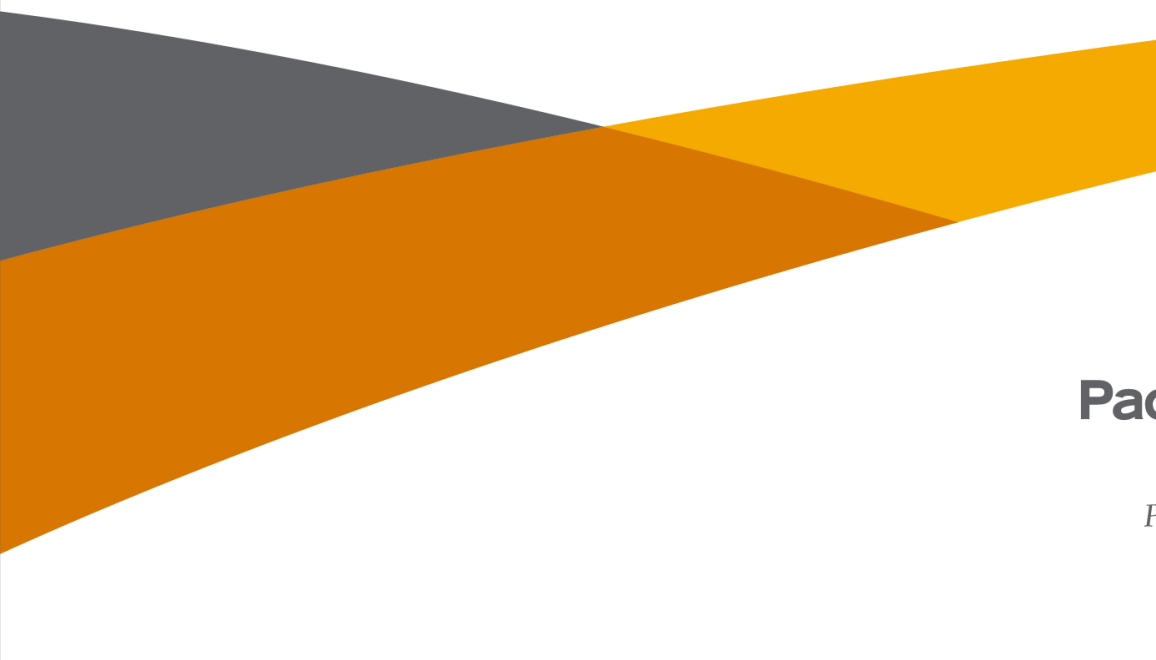




\section{DISCLAIMER}

This report was prepared as an account of work sponsored by an agency of the United States Government. Neither the United States Government nor any agency thereof, nor Battelle Memorial Institute, nor any of their employees, makes any warranty, express or implied, or assumes any legal liability or responsibility for the accuracy, completeness, or usefulness of any information, apparatus, product, or process disclosed, or represents that its use would not infringe privately owned rights. Reference herein to any specific commercial product, process, or service by trade name, trademark, manufacturer, or otherwise does not necessarily constitute or imply its endorsement, recommendation, or favoring by the United States Government or any agency thereof, or Battelle Memorial Institute. The views and opinions of authors expressed herein do not necessarily state or reflect those of the United States Government or any agency thereof.

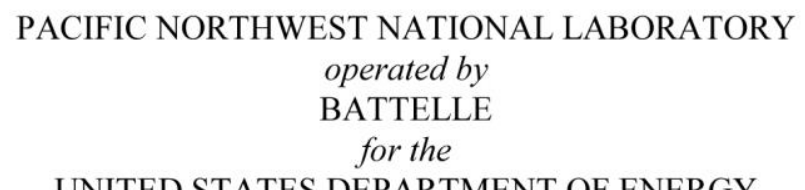

UNITED STATES DEPARTMENT OF ENERGY under Contract DE-AC05-76RL01830

Printed in the United States of America

$$
\begin{aligned}
& \text { Available to DOE and DOE contractors from the } \\
& \text { Office of Scientific and Technical Information, } \\
& \text { P.0. Box 62, Oak Ridge, TN 37831-0062; } \\
& \text { ph: (865) 576-8401 } \\
& \text { fax: (865) 576-5728 } \\
& \text { email: reports@adonis.osti.gov }
\end{aligned}
$$

Available to the public from the National Technical Information Service 5301 Shawnee Rd., Alexandria, VA 22312 ph: (800) 553-NTIS (6847)

email: orders@ntis.gov <http://www.ntis.gov/about/form.aspx> Online ordering: http://www.ntis.gov 


\section{Summary of the Undergraduate Mentoring Assistance Program for PNNL}

PNNL.12.007

(June 2012 - September 2012)

JM Schwantes

March 31, 2013

Prepared for

the U.S. Department of Energy

under Contract DE-AC05-76RL01830

Pacific Northwest National Laboratory

Richland, Washington 99352 



\title{
Summary of Students and Projects
}

\author{
$\underline{\text { Kelly Fitzgerald }}$
}

Kelly Fitzgerald assisted with laboratory testing for an ongoing R\&D project known as Electrochemically Modulated Separation (EMS) for on-line rapid preseparations of actinides prior to mass spectrometry analysis.

\section{$\underline{\text { Ryne Burgess }}$}

Ryne Burgess used SCALE 5.1 ORIGEN-ARP to predict isotope libraries for the Units 1, 2 and 3 reactors and Unit 4 spent fuel pool for comparing against measurements of environmental sampled collected at the site in order to identify the source terms of the accident. Comparison of the cesium 134/137 and cesium 136/137 ratios observed in environmental samples and ORIGEN-ARP predictions indicated that the Unit 4 Spent Fuel Pool did not significantly contribute to radionuclide release during the Fukushima Daiichi accident.

\section{Student Research Contributions}

A total of two formal reports and two presentations were provided in part with support from Undergraduate Mentoring Assistance Program (UMAP). A complete description of these references is listed below.

\section{Reports (2)}

Burgess RD, JM Schwantes, and S Reese. 2013. Origen-ARP Source Term Analysis to determine the contribution from the Unit 4 Spent Fuel Pool to the release from the Fukushima Daiichi Nuclear Power Plant Accident. PNNL-22057, Pacific Northwest National Laboratory, Richland, WA.

Ryne D. Burgess, Jon M. Schwantes, Steven R. Reese. 2012. ORIGEN-ARP Source Term Analysis to determine the contribution from the Unit 4 Spent Fuel Pool to the release from the Fukushima Daiichi Nuclear Power Plant Accident (PNNL-22057)

\section{Presentations (2)}

Schwantes JM, CR Orton, RA Clark, and RD Burgess. 2012. "Releases from the Fukushima Daiichi nuclear accident as remote indicators of source identification, extent of release, and state of damaged spent nuclear fuel." Presented by Jon Schwantes at Richard Clark's Dissertation, Columbia, MO on September 18, 2012. PNNL-SA-90729.

Ryne D. Burgess, Jon M. Schwantes, Steven R. Reese ORIGEN-ARP Source Term Analysis to determine the contribution from the Unit 4 Spent Fuel Pool to the release from the Fukushima Daiichi Nuclear Power Plant Accident (PNNL-22057) 


\section{Benefits (to the laboratory, the mentors, and the students)}

UMAP has provided a number of important benefits to our laboratory, our staff and our mentees. First and foremost, UMAP supported quality National Laboratory mentoring of university undergraduate students. Mentoring is a necessary part of the education of all incoming staff to the National Laboratory system due to the particular nature of the research being conducted at these institutions. Secondly, this Program provided support to staff for activities that are often unfunded. To an extent, mentoring is a normal part of many staff members' days. The mentoring staff has active and ongoing relationships with academia and as such, often hosts students from these institutions for extended periods of time at the Laboratory. However, funding to support activities specific to mentoring are almost never captured within scope that is inherently "research and development" in nature. This leaves staff to often volunteer their time to interact with and mentor students from academia. UMAP has supported these often overlooked activities.

\section{Challenges}

The single biggest challenge to mentoring undergraduate students at the national laboratory was identifying a mentor that was able and willing to commit the time required to mentor a student. Last year, was the first time PNNL participated in this program. We were asked to support two UMAP students for the summer on relatively short notice, however, which made finding appropriate and available mentors for these students difficult. In an attempt to insulate these students from the challenging work schedules of their mentors, students were assigned more than one mentor for the summer. For instance, while I was away on business and personal travel during Ryne Burgess' internship, another staff member (Brian Collins) took over mentoring activities during those times.

\section{Summary of Laboratory Mentor Interactions with Students' Home Universities \& Significant Events}

\section{December 2012}

- Jon Schwantes, Ryne Burgess and Professor Steve Reese traveled to Los Alamos National Laboratory to participate in the NFUSP Culmination Meeting. 



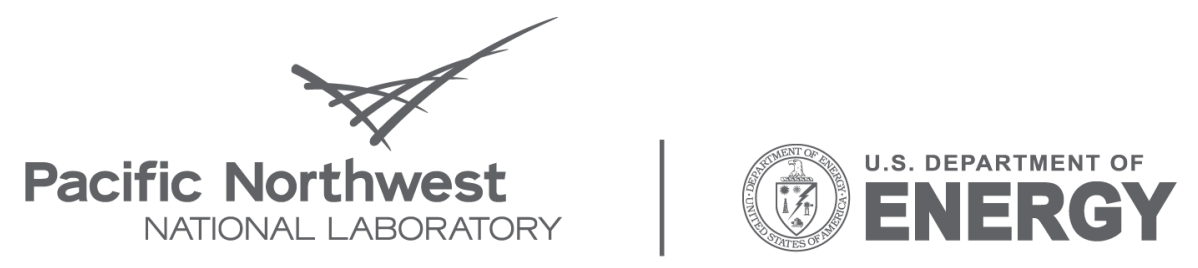

Proudly Operated by Battelle Since 1965

902 Battelle Boulevard

P.O. Box 999

Richland, WA 99352

1-888-375-PNNL (7665)

www.pnl.gov 